\title{
Policy Implementation of Handling Security Management in District Gorontalo
}

\author{
Nur Istiyan Harun ${ }^{1}$, Khairul Haras ${ }^{2}$ \\ \{isty.harunc@gmail.com $\left.{ }^{1}\right\}$ \\ Universitas Gorontalo ${ }^{1,2}$
}

\begin{abstract}
This paper aims to analyze how the implementation of slum settlement policies in the Village of Gorontalo District. The targets include identifying local policies as well as factors affecting the implementation of duties in slum settlement management in Kayubulan Village, identifying implementation variables and analyzing the implementation of activities. Smith's theory in Tachjan, emphasizes that in the implementation process there are four variables to consider. The four variables are a unity that mutually influence and interact reciprocally, therefore there are tensions that can lead to the emergence of protests. The four variables in the implementation of public policy, namely; programs implemented, target groups, implementing elements and environmental factors. This research uses case study method. Because of this specific research would like to explain how the implementation of slum settlement policies in the Village District Kayubulan Limboto Gorontalo District. From the research results, the timeliness of implementation affects the results of activities undertaken. Judging from the environmental characteristics there are still some points of the region such as in the outskirts of Lake Limboto that still have not been touched by the slum handling policy. The results of the implementation of slum environmental activities have given physical changes to the environment, the benefits received by society have been felt not yet able to overcome the slum.
\end{abstract}

Keywords: Policy Implementation, Slum Areas, Kayubulan Village

\section{Introduction}

This research aims to analyze how the implementation of slum settlement management policies in Kayubulan Village, Limboto District, Gorontalo Regency. The targets include covering the identification of regional policies and the factors that influence the implementation of tasks in handling slums in Kayubulan Village and analyzing the implementation of activities.

In Indonesia, the decline in the quality of rural and urban housing environments is often found in densely populated areas, such as urban slums. Optimal land use, chaotic form of buildings, inadequate environmental facilities and infrastructure is a sign of the decline [1], [2].

Slums are a classic problem that has long developed in big cities. Nevertheless, the problem of slum settlements remains a problem and the main obstacle to urban development. The rapid pace of urban development makes land use increasingly competitive, while on the other hand, the development of the city becomes an attraction of urbanization which 
ultimately leads to high levels of demand for dwellings in the city. The rapid development of the urban population, which generally comes from urbanization cannot always be balanced by the ability of city services so that it has resulted in an increasingly widespread slum area.

Based on act number 1 of 2011 concerning housing and residential areas, slums are uninhabitable settlements due to building irregularities, high levels of building density, and the quality of buildings and facilities and infrastructure that do not meet the requirements [3].

In addition, slums are also residential environments whose quality is very uninhabitable, the characteristics include being on land that is not in accordance with the designation / layout, very high building density in a very limited area, prone to social diseases and environmental diseases, and irregularities in buildings, very low quality of buildings, inadequate infrastructure and endangering the lives and livelihoods of their inhabitants.

Widespread urban slum environments have had an impact on increasing the frequency of fire and flood disasters in urban areas, increasing potential vulnerabilities and social conflicts, declining levels of public health, declining quality of infrastructure service and settlement facilities. The complaint that is most often conveyed regarding the settlements of the poor is the low quality of the environment that is considered a part of the city that needs to be removed.

In determining the area for the implementation of slum handling, it is based on several regulations determined by the government, both from the central level to the regional level. In determining the region itself can be seen from the following statutory provisions, namely; act number 26 of 2007 concerning Spatial Planning, act number 6 of 2014 concerning Villages, Division of Affairs according to act number 23 of 2014 concerning Regional Government, Cities and Urban Areas according to act number 23 of 2014 concerning Local Governments, slum areas and settlements according to Local Government act and act number 1 of 2011 concerning Housing and Slum Settlements, the Handling Authority of Slum Settlements based on Area (Local Government Law), Urban Areas according to act number 23 of 2014 concerning Regional Government, Handling of Slums according to act number 1 of 2011 concerning Housing and Settlements .

Currently Kayubulan Village, Limboto Subdistrict is the attention of the Gorontalo District community, and housing problems in Kayubulan are categorized as slums according to the data in the KOTAKU program (formerly P2KKP). This is because, there are many garbage problems that pollute the environment and damaged roads, besides that the problem of household waste water disposal is equally important because of the location of Kayubulan Village in the middle of Gorontalo Regency.

Therefore, this research is important to do, to see what policies made by the Gorontalo District Government for the problem of slums in Kayubulan Village, how the policies are implemented and what factors influence the implementation of policies in the field.

\subsection{Slums Area}

Slum areas are areas where houses and residential conditions in the region are very poor. The house and facilities and infrastructure are not in accordance with the applicable standards, both standard requirements, building density, requirements for healthy houses, the need for clean water facilities, sanitation and the requirements for completeness of road infrastructure, open space, and the completeness of other social facilities. 
The characteristics of slums area, as expressed by Prof. DR. Parsudi Suparlan is:

1. Public facilities that are lacking or inadequate.

2. Occupancy conditions of houses and settlements as well as the use of space reflect the inadequate or poor residents.

3. There is a high level of frequency and volume density in the use of spaces in slums so that it reflects the chaos of spatial planning and the economic powerlessness of its inhabitants.

4. Slums are community units that live separately with clear cultural and social boundaries, which are realized as: A single community, located on state land, and therefore can be classified as wild dwelling; Single community unit that i s part of an RT or a RW.

5. The slum dwellers are socially and economically not homogeneous, their citizens have diverse livelihoods and levels of density, as well as their origins. In slum settlements, there are also known social layers based on their different economic abilities.

6. Most slum dwellers are those who work in the informal sector or have additional livelihoods in the informal sector.

The occurrence of slums is caused by several aspects, namely physical (infrastructure), social (attitude and behavior), and economic aspects (low community income). Therefore, the handling of slum settlements must be carried out in an integrated manner by involving the government, community, and existing stakeholders.

Efforts to deal with slums only on physical or economic aspects can indeed solve the problem of slums. However, it will have the potential to become a slum again if it is not accompanied by changes in the attitudes and behavior of the community. Changes in attitudes and behavior of the community were carried out through community empowerment, ranging from socialization activities, capacity building, planning, implementation, monitoring and maintenance.

\subsection{Public Policy Implementation}

Many experts provide limitations or definitions of the implementation of public policy, in this study researchers poured several theories from several experts, and used one theory to answer the research questions adjusted to the aspects to be studied. Van Meter and Van define the implementation of public policy as actions of previous decisions. These actions include efforts to change decisions into operational actions within a certain period of time or in order to continue efforts to achieve large and small changes determined by policy decisions made by public organizations directed to achieve predetermined goals [4].

Edward III suggested that "policy implementation, is the stage of policy making between the establishment of a policy, and the consequences of the policy for the people whom it affects". Whereas Grindle suggested that" "implementation is general procces of administrative action that can be investigated at specific program level" [5]. 
From the description above, it is obtained an illustration that, the implementation of public policy is an administrative activity process that is carried out after the policy is determined / approved. This activity is located between policy formulation and policy evaluation.

According to Adam Smith policy implementation is seen as a process or plot. Smith's model views the policy implementation process from the perspective of social and political change, where policies made by the government aim to make improvements or changes in society as a target group. In the implementation process according to Smith there are four variables that need to be considered, the four variables do not stand alone, making it an entity that mutually influence and interact mutually, therefore there are tensions that can cause protests, even actions physical where this requires the enforcement of new institutions to realize the goals of the policy [5]. The four variables in the implementation of public policies are:

1. Policies implemented.

2. Target groups, namely community groups that are targeted, and expected to receive benefits from the program, change or increase.

3. Implementator, whether an organization or individual, who is responsible for the management, implementation and supervision of the implementation process.

4. Environmental factors, elements in the environment that influence policy implementation such as cultural, social, economic and political aspects.

\subsection{Implementation of Slum Settlement Management policies}

Settlements are often called housing and vice versa. Settlement comes from the word housing in English which means housing and the word human settlement which means settlement. Housing gives the impression of a house or a collection of houses along with the environmental infrastructure and facilities. Housing focuses on physical or inanimate objects, namely houses and land settlement. Whereas settlements give the impression of settlers or groups of settlers along with their attitudes and behavior in the environment, so that settlements focus on something that is not physical or inanimate objects namely human. Thus housing and settlements are two things that are inseparable and very closely related, essentially complementary.

Based on act number 1 of 2011 concerning housing and residential areas, slums are uninhabitable settlements due to building irregularities, high levels of building density, and the quality of buildings and facilities and infrastructure that do not meet the requirements [3].

The problem of slum settlements is a problem of settlement management which is closely related to the provision of housing for weak economic communities that arise in developing cities. Some forms of handling slum settlements as a form of implementation of public policies have been implemented by the government, including a revolving fund program in the form of financial assistance for home improvement and funding for business capital. So far the existing program has not been able to improve the existing conditions. This is because policy makers do not fully understand the existing problems as forming characteristics of slums and handling that is only partially carried out so that the program will not be completed yet another problem will arise. So that the handling carried out has not been able to solve the problem significantly.

In this research, the implementation of public policy in handling slums is seen from four aspects. First, the program implemented to solve the problem of slums in Kayubulan Village. Second, Target groups, namely community groups that are targeted, and are expected to benefit from the program, change or increase. Third, the implementing element (implementor), whether an organization or individual, who is responsible for the management, 
implementation and oversight of the implementation process. Fourth, environmental factors, namely physical and non-physical slum handling programs can provide changes to the environment of Kayubulan village.

\section{Methodology}

In this study researchers used a type of qualitative research, using case study methods. Case studies are used to explore and seek more information on the implementation of slum handling policies in the outskirts of Lake Limboto. This type of research is used because descriptive analysis is the study of finding facts with the right interpretation, accurately describing the properties of some phenomena, groups or individuals, determining the frequency of occurrence of a situation. The analysis is done based on the data collected after the incident.

There are two types of data needed in this research, namely primary data and secondary data. To obtain both types of data, this paper uses three techniques, namely interview, observation and documentary.

With interview techniques, information and data can be obtained about the policies implemented as solutions for slum areas. The observation is used in data retrieval with systematic observation and recording in the field to obtain the necessary data related to how the implementation of slum settlement policies and what factors influence in implementing policies in slums area. And the last one is a documentary, where the writer takes data by studying various documents related to slum handling policies in Kayubulan Village.

Operational definition is the operationalization of research variables used to search data and data collection, to analyze data and to interpret the results of its analysis. The operational definition of the four variables to be an indicator of measurement is the program implemented, target groups, implementing elements and environmental factors.

\section{Result and Discussion}

Kayubulan Village is part of Limboto sub-district as the capital of the sub-district located in the center of the district capital. The position of the sub-urban village area $\pm 15 \mathrm{~m}$ above sea level. Typology of Kayubulan village itself is lowland with flat land characteristics.

Kayubulan Village is part of Limboto sub-district as the capital of the sub-district located in the center of the district capital. The position of the sub-urban village area $\pm 15 \mathrm{~m}$ above sea level. Judging from the geographical conditions of Kayubulan village, which is in the Limboto sub-district, is the most strategic area with borders, the north bordering Kayumerah subdistrict bordered by Biyonga river, south bounded by Limboto lake, west bounded by Hunggaluwa village bordered by Biyonga river and the east side is bordered by the hapisulawa village which is bordered by roads and rice fields.

Kayubulan Village is part of the Kec. Limboto with population based on BPS data is 7395 inhabitants with 3693 male population and 3702 female number. Kayubulan Village is a part of Limboto sub-district which is a trading area that has the potential to improve the welfare of the community in Kayubulan village. Judging from the location and geographical conditions Kayubulan village has the potential to develop service sector businesses, trade and micro small businesses because of its strategic location in the central government of Gorontalo.Kelubulan village is part of Limboto sub-district as the capital of the district located 
in the center of the district capital. The position of the sub-urban village area $\pm 15 \mathrm{~m}$ above sea level. Typology of Kayubulan village itself is lowland with flat land characteristics.

Some kayubulan urban areas are located in watersheds (DAS) and tidal areas (around limboto lakes) so that the problem of inundation or flooding is a familiar thing to address some residential areas in the Kayubulan village. with the presence of new buildings built on water catchment areas will have an impact on residential areas in the watershed or tidal areas considering the Kayubulan village is a village with typographic characteristics is lowland. For example in the environment 5 and 4 in the rainy season floods often occur and soak the homes of residents who are near the limboto lake.
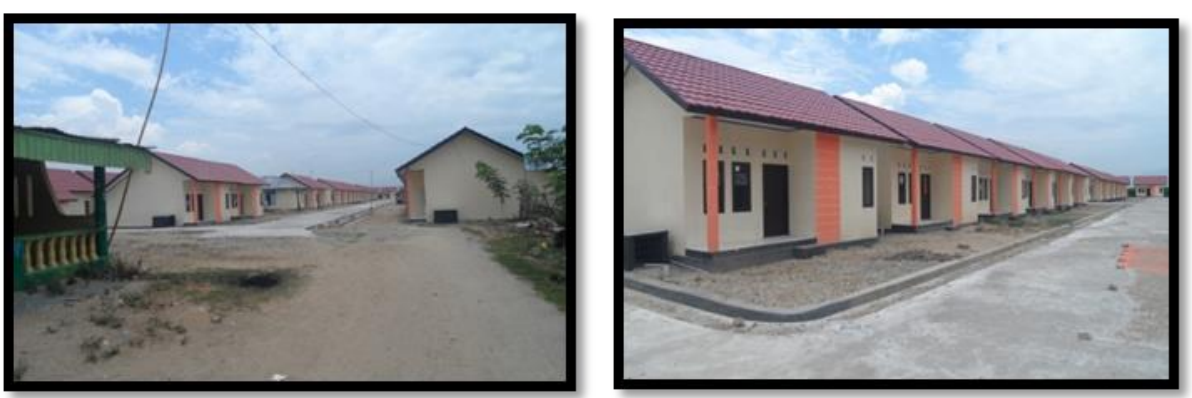

Conditions of Fishermen's Village on the coast of Limboto Lake before the flood
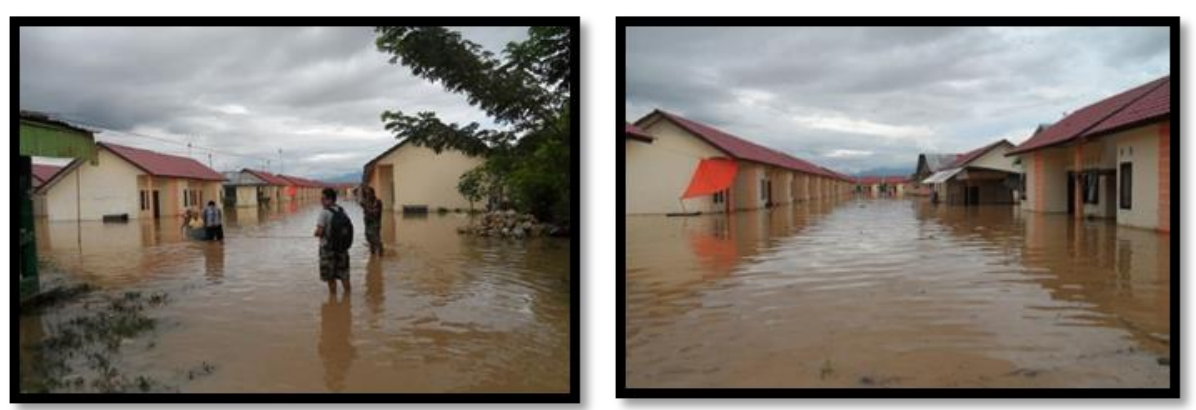

Conditions of Fishermen Village on the coast of Limboto Lake after the flood

\subsection{Implementation of slum settlement handling policy in kayubulan village, Limboto District,}

\section{Gorontalo Regency}

To see how the implementation of slum handling in Kayubulan Village, the researchers used the indicators contained in Adam Smith's theory, namely; (1). Programs implemented, (2) Target Groups or areas that are targeted by the policy, (3). Implementator, and (4) Environmental factors.

In the results of the study, there were several implementations in the handling of slums in Kayubulan village with the basis of the Regent's Decree number 644/22 / IX / 2014 concerning the Determination of the Locations of Slum and Slum Settlements in Gorontalo District, through the adam smith theory some research results found in the field, is: 


\section{The policy implemented}

Based on the results of the observation, there are two programs implemented to deal with this slum problem, namely the housing and settlement handling program and the slum quality improvement program. Both of these programs are a step towards efforts to create a slum-free city through the 100-0-100 movement that has been included in the 2015-2019 RPJMN, the target of which is $100 \%$ drinking water service, $0 \%$ slum area, and $100 \%$ decent sanitation for district / city government it is expected to be able to mobilize the collaboration of many sectors by many parties to be able to mobilize a variety of resources and funding sources from the central, provincial, city / district, sub-district, kelurahan levels including the private sector, universities and other caring groups through integrated programs to reduce slums from 38,431 $\mathrm{Ha}$ of slum areas to become $0 \mathrm{Ha}$ slum in 2019 so that "City is livable, productive and sustainable"

\section{Target Groups}

Every public policy must have a clear and measurable standard and a policy objective. With these provisions the goal can be realized. In the case of handling the slums, the target is the community of Kayubulan sub-district in the neighborhood I and Environment II, Limboto sub-district, Gorontalo district. In this area is a slum area that has been set in the foundation of the Regent's Decree Number 644/22 / IX / 2014 concerning the Determination of the Location of Slum and Slum Settlement in Gorontalo District. In accordance with the results of the interview from Ms. Lieke Jamali, ST, MM, as the head of the Gorntalo District Office of Public Works and Spatial Planning, he said that "all the issues concerning the handling of slum areas in Gorontalo regency are carried out in accordance with government policy, that is in accordance with the Decree of the Regent Number 644/22 / IX / 2014 concerning the Determination of the Locations of Slum and Slum Settlement in Gorontalo District. So all forms of slum handling that enter the Gorontalo district must be based on this decree. And in 2016 the Regent's Decree was revised in accordance with the applicable provisions. ".

\section{Implementator}

In the implementation of the slum handling program implemented in the keyubulan village, it was carried out by two different agencies. That is the Public Works and Spatial Planning service that carries out the Housing and Settlement Handling Program and the Gorontalo Provincial Settlement Development Work Unit that implements the Kayubulan Region slum quality improvement program. Following are the details of activities carried out by the relevant agencies:

a. Gorontalo District Public Works and Spatial Planning Office

In the framework of effort to reduce clean water in the Kayubulan village and for handling slums areas,through housing and settlment handling programs, the local government, in this case the public works agency and the Gorontalo district out activities to provide and organize environmental drainage networks by making limbal dense communal settlements widely of 50 $\mathrm{m} 2$.

b. Gorontalo Province Resettlement Work Unit.

In accordance with the direction and policy of handling slum settlements by the head of the settlement development work unit of Gorontalo Province there are: 
Table 1.

\begin{tabular}{lll}
\hline \multicolumn{1}{c}{ Slum indikator } & \multicolumn{1}{c}{ Slum Settlement Patterns } \\
\hline a. Building Conditions & a. Prevention \\
b. Environmental road conditions & b. Quality improvement \\
c. Environmental drainage conditions & c. Management \\
d. Condition of clean water supply & \\
e. Waste management conditions & \\
f. Waste management conditions & \\
g. Fire safety conditions & \\
\hline
\end{tabular}

So the work unit development and the Settlement area made the Macadam Road along 3,522 meters, the Road Improvement of the Paving Stone Environment 2,594.5 meters, the Making of the Channel along 161.19 meters, the Making of the 100 meter Land Retaining Talud. However, from these four activities that have just been carried out is the construction of paving stone and waterways. In this handling activity, the broad target of slums in the Kayubulan village is $4.21 \mathrm{Ha}$. With a population of 408 people / 103 families.

In the implementation of this program also involved the P2KP Facilitator Team which has now been renamed the KOTAKU Program Team (City without Slums). By interviewing Mr. Sutami as the Kotaku Coordinator in the Gorontalo district area, all this time, they have always synergized with the government if the government asks them to facilitate the program to be carried out, such as the construction of environmental roads and waterways in the district. But for the work it was done by a third party contractor.

\section{Environmental factors}

Physically the environment of Kayubulan village is indeed a slum area. This can be seen from the stipulation of the Regent's Decree which was explained earlier, therefore the timber estate area is an area that is prioritized in handling slums either in the pattern of handling infrastructure. But there are some areas such as limboto lake fringes, which based on observations, are classified as slum indicators such as roads, damaged waterways, but there are no government actions to deal with slums in the area, even though there are areas that are potentially flood prone, because the government prioritizes slum handling in suburban areas.

non-physically, in the form of the life of the kububulan community supporting the slum handling program, seen from the mindset of the kububulan community who are people in urban areas, of course they also do not want that their area is included in the slum indicator. And this is their hope that was also conveyed during the Socialization of the KOTAKU Program Facilitator Team when they went down in the area.

\subsection{Factors Affecting Slum Settlement}

\subsubsection{Inhibiting factors Handling slums:}

Properly, the implementation of slum handling in the Kayubulan village is inseparable from several factors that hinder the performance of the parties concerned. The obstacle that researchers get in the field is:

\section{Budget,}

The success of a program certainly cannot be separated from the support of several parties or the material, in this case in the form of a budget, namely the budget used to implement this slum handling program is the budget received from the central (APBN). So that in launching a 
program the budget disbursement process takes a long time, moreover the target until 2019 is already $0 \%$ slum throughout Indonesia according to government regulations and results in obstruction of the implementation of programs that have been adjusted to the implementation schedule.

\section{Land acquisition for the location of program implementation}

In this case, most of the people in the kelubulan village did not want to give land to be granted for the implementation of the program. the result of an interview from one of Cipta Karya staff at the Gorontalo District Public Works and Spatial Planning Office, Mr. Abdul Musaktian Ibrahim, ST, said that in the Peraturah or Juknis in the implementation of a program that addresses environmental problems, the land used is land that is land-free and or the land granted if the location is precisely distributed to the land area owned by the community.

3. Lack of willingness to empower the environment itself.

There are still some people who only depend on government assistance without developing their own environmental quality.

\subsubsection{Slum Handling Driving Factors:}

The driving factor for handling slum settlements in Gorontalo Regency is:

\section{Coordination}

Problems such as a budget that is very difficult in the lobby if the handling requires a large enough budget or the budget is late in disbursement, through interviews that have been carried out in the field that by doing good coordination with all parties, especially the central government, so that all program targets have been implemented well although still there are several obstacles.

2. Socialization

The running of the socialization in the Kayubulan village area can also help because the government often gathers community representatives in the kelurahan office when implementing the budgeting plan and program implementation by the government. so that the community is able to understand the intent and purpose of the government that is doing development in the Kayubulan village.

\section{Conclusion}

The The results of this study can be concluded: first, the implementation of the slum quality improvement program and the handling of housing and settlements that have been implemented and built firmly in order to realize the national target namely, the 2015-2019 RPJMN especially in the field of copyright creation has set a target of achieving $100 \%$ access to services drinking water $100 \%, 0 \%$ slum settlements and proper sanitation access $100 \%$ by 2019. This program involves all elements for the implementation of the program. Although there are still some deficiencies in the implementation, such as there are some areas that have not been reached by the government in the limboto lake suburbs, which are considered included in the slum area indicators. This is because the government prioritizes slum handling in suburban areas. 
Second, through the implementation of slum handling that has involved the community can provide a positive influence so that whatever form of program that will be implemented then the community will automatically give their participation as citizens of the Unitary Republic of Indonesia.

\section{References}

[1] M. Mardiharini, "Family-Coping Strategies in Maintaining Welfare During The Economic Crisis In Indonesia: A case study in rural and urban areas in Bogor, West Java, Indonesia,” 2016.

[2] P. Monkkonen, "Housing deficits as a frame for housing policy: demographic change, economic crisis and household formation in Indonesia," Int. J. Hous. Policy, vol. 13, no. 3, pp. 247-267, 2013.

[3] A. Annisa, "Slum Settlement Revitalization in Purwogondo Village as a Tourism Village Special Interest in Home Tofu Industry." 2018.

[4] W. Budi, Public Policy (Theory, Process and Case Study). Jakarta: CAPS, 2014.

[5] Tachjan, Public Policy Implementation. Contents: AIPI, 2006. 